Dept. of Poultry Diseases,

Fac, of Vet. Med., Assiut University

\title{
EVALUATION OF AN INFECTOUS BURSAL DISEASE VIRUS-ANTIBODY COMPLEX FOR VACCINATION \\ OF COMMERCIAL CHICKS WITH MATERNAL IMMUNITY (With 3 Tables)
}

By

\author{
M. ALY;S. MOUSA and A. IBRAHIM* \\ * South Valley University \\ (Received at 28/6/2001)
}

تقييم لقاح يحوي مخلوط من فيروس مرض التهاب حوهلئة فابريسيي

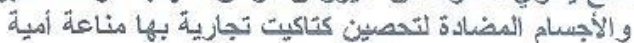

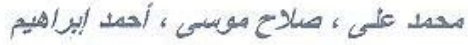

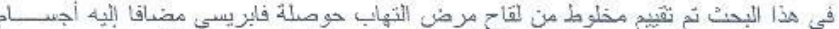

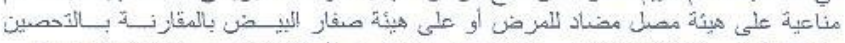

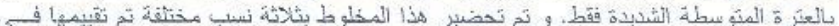

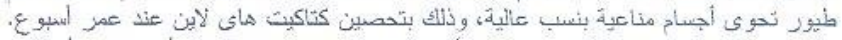

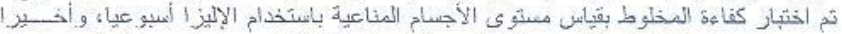

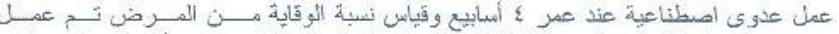

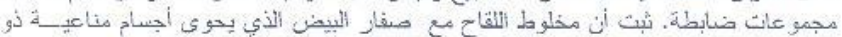

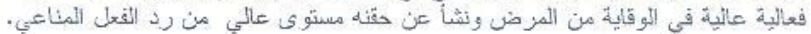

\section{SUMMARY}

An infectious bursal disease virus-antibody complex (IBDV-Ab) was evaluated for vaccination of young chicks possessing high titer of maternal antibodies in comparison with a living intermediate-plus vaccine. IBDV-Ab complex was prepared by mixing live IBDV vaccine and $\mathrm{Ab}$ contained in either whole hyperimmune-serum or hyperimmunized $\mathrm{cgg}$ yolk. Three formulations of IBDV-Ab were constructed using different doses of serum or yolk. The efficacy of the mixtures were tested after vaccination of 7-day-old Hy-Line cockerels by subcutaneous injection and challenge at 4 weeks of age by estimation 
of antibody titers, mortalitics and bursal lesions. Antibodies against IBDV were measured before and after vaccination using ELISA. Negative and positive controls were included. Chicks receiving IBDV$\mathrm{Ab}$ complex werc protected from challenge with varying degrees superior to those vaccinated only with the intermediate-plus vaccine. Complexes prepared from vaccine and egg yolk resulted in better protcction rates than complexes prepared from vaccine and IBDV antiserum.

Key words: Vaccine Antibody complex for IBD.

\section{INTRODUCTION}

Infectious bursal discase (IBD) is an acute, highly contagious viral disease targeting primarily $B$ cells of young chickens and characterized by severe damage of the bursa of Fabricius and inmunosuppression (Lukert and Saif, 1997).

The principle method of IBD control is by vaccination. Several vaccines against IBD virus (IBDV) are available commercially. In terms of virulence, these vaccines range from mild to intermediate to intermediate-plus (Winterfield and Thacker, 1978 and Guittet et al., 1992).

In recent years, hyperimmunization of breeder hens against IBIDV become a routine practice. Such programs have been practiced to provide the progeny with passive IBDV immunity. However, this passive immunity is not uniform between chickens from the same flock (Weisman and Hitchner, 1978) or even from the same hen (Rives et al., 1991).

Mild and intermediate IBDV vaccines are believed to be ncutralized by maternally derived antibodies in a higher portion of a flock (Winterfield and Thacker, 1978). On the other hand, the intermediate-plus vaccines are superior to the mild or intermediate vaccines in giving immunity to commercial chickens with maternal antibodies, becausc intermediate-plus vaccines are less affected by maternal antibodies, (Winterfield et al., 1980).

Whitffill et al. (1995) and Haddad et al. (1997) found that administration of IBDV- BDA complex vaccine at one day of age can induce active immunity and protection against a standard IBDV chal lenge in the face of variable levels of maternal IBDV immunity. 
The objective of this study was to evaluate a novel IBDV vaccine prepared from vaccine-antibody mixture for vaccination of chicks possessed high levels of IBDV maternally derived antibodies.

\section{MATERIALS and METHODS}

IBDV vaccine:

Less attenuated IBDV vaccine (strain 228E, Intervet) $\left(\mathrm{EID}_{\text {so }}\right.$ per field dose equal to $10^{5.7}$ ) was used in this study.

\section{Chickens:}

The chickens used were commercial Hy-line cockerels. Chickens were obtained as one-day-old chicks and kept on a wire net floor in complete isolation until uscd.

Challenge virus:

A highly virulent IBD field virus previously isolated from the bursae of naturally infected chicks (Saif-Edin ct al., 1996) was used for challenge.

\section{Chicken embryos:}

10-day-old embryonated chicken eggs were provided by the Poultry Farm of the Faculty of Agriculture, Assiut University and used for titeration of IBDV.

\section{IBDV antiserum and hyperimmunized egg yolk:}

Serum and eggs were obtained from $\mathrm{Hy}$-line layers vaccinated three times with an intermediate IBDV vaccine and poostered with an oil-emulsion vaccine at 18 and 24 weeks of age. Serum and eggs were collected 3 weeks after the last vaccination. Yolk was obtained by breaking the eggs into a house hold yolk separator and placed in sample cup then mixed with sterile wood applicator stick. Yolk was diluted 1:2 in buffer solution and kept at $-20 \mathrm{C}$. Sera and yolk were titrated using EI.ISA test and used for vaccine preparation.

\section{Serum samples:}

10 serum samples from each experimental group were collected at one day of age and then at one week intervals. Scra were subjected individually to ELISA test for estimation of IBDV antibodies.

ELISA test:

Yolk as well as serum samples were assayed at a final dilution of 1:500 for antibodies to IBDV, using a commercial ELISA system (Flock-Chik Agritech system Portland, Maine). The test procedurc followed the directions supplied with the kits and EIISA titers were logarithmically transformed. 


\section{Vaccine virus titeration:}

The vaccine virus was titrated using 10-day-old fertile chicken embryos. The titer of the vaccine virus was expressed as mean embryo infective dose $\left(\mathrm{EID}_{50}\right) / \mathrm{ml}$.

Bursa / body weight ratios:

At 2, 3, and 4 weeks of agc. five birds from each group were weighted immediately after they had been killed. The bursae of Fabricius were removed and weighted. Bursa / body weight ratios were calculated as pereentages for each bird and expressed as arithmetic means of groups of birds.

Challenge:

Chickens were challenged at 4 weeks of age. An IBD field virus previously isolated from bursae of infected chicks, identified and titrated to contain $100 \mathrm{FID}_{50}$ in $0.05 \mathrm{ml}$ was used for intraoccular instillation in birds to be challenged. This dose was shown to cause $80-100 \%$ mortality in susceptible chicks.

IBDV-Ab complexes:

The titers of IBDV vaccine (strain 228E), IBDV antiserum and IBDV hyperimmunized egg yolk were determined to calculate the specific volume of each that is required to prepare the desired number of doses of the mixtures. Vaccine formulations (referred to as IBDV-Ab complex vaccinc) were prepared as follows: complex 1 contained a specific volume of IBDV suspension containing $100 \mathrm{EID}_{50}$ of UBDV vaccine and an equal volume of IBDV antiserum of 3200,4100 , and 6400 ELISA titers; complex 2 contained a specific volume of IBDV suspension containing $100 \mathrm{EID}_{50}$ of IBDV vaccinc and an equal volume of IBDV hyperimmunized egg yolk of 3100,4200 , and 5800 ELISA titers.

All mixtures were incubated at room temperature for 1 hour with gentlc shaking every 15 minutes. Each formulation was kept over night at $4 \mathrm{C}$ until used.

Evaluation criteria:

All mixture formulations were evaluated according to the following criteria:

1- Fstimation of IBDV antibodies using ELISA test

2- Bursa/Body weight ratios.

3-Morbidity and mortality rates post-challenge.

Experimental design:

A number of 400 commercial Hy-Line cockercls were divided into 8 equal groups (1-8). Chicks of groups 1,2 , and 3 were inoculated 
subcutaneously with mixtures of strain 228E of IBDV and IBDV antiserum of 3200,4100 and 6400 ELISA titers, respectively. Chicks of groups 4,5 , and 6 were inoculated subcutaneously with mixtures of strain 228E of IBDV and IBDV hyperimmunized egg yolk of 3100 4200 and 5800 ELISA titers, respectively. Chicks of group 7 were vaccinated via eye drop method with strain $228 \mathrm{E}$ of IBDV. Group 8 served as unvaccinated control

All groups were titrated for maternally derived IBDV antibodies at one day of age using ELISA test. Ten serum samples were collected cvery week from each group and subjected to ELISA test for estimation of IBDV antibodies. wecks of age

The bursa/body weight ratios were calculated at 2,3 , and 4

At 4 weeks of age, 10 birds from each group were challenged intraoccularly with very virulent IBDV. All challenged groups were kept under observation for 8 days, morbidity and mortality rates were recorded. At the end of observation period survivors as well as controls were sacrificed, necropsied and bursae were examined.

\section{RESULTS}

Level of maternally derived IBDV antibodies at one-day-old:

The ELISA test results (Table, 1) indicated that all one-day-old chicks used in this study possessed high titers (4860-5432) of IBDV maternal antibodies.

ELISA titers at week intervals in different groups:

The ELISA titers of IBDV antibodies for each group at week intervals are shown in Table (1). Results indicated that ELISA titers for IBDV antibodies were high in groups immunized with vaccine-yolk complex, then groups immunized with vaccine-antiserum complex. Low LLISA titers were recorded in the group vaccinated only with IBDV vaccine

Bursa / body weight ratios:

Table (2) showed that all vaccinated groups had a lower bursa/ body weight ratio than unvaccinated control group. On the other hand, groups inoculated with mixtures of IBDV vaccine and either of IBDV antiserum or hyperimmunized yolk showed a higher bursa/body weight ratio than the group inoculated only with IBDV vaccine.

Results of challenge:

The protection rate for each challenged group is shown in table (3). The highest protection rate from mortality was recorded in groups 
inoculated with vaccinc-hyperimmune yolk complex ( $80-90 \%$ ) followed by those inoculated with vaccine-antiserum complex $(70-80 \%)$. The protection rate in the group vaccinated only with IBDV vaccine was $50 \%$, while in unvaccinated challenged control group the protection rate was $20 \%$.

\section{DISCUSSION}

The principal method to control IBD is by vaccination. However, many reports demonstrated the failure of IBDV vaccination due to inability of some vaccine strains to overcome the high levels of maternal antibodies and induced insufficient immunity (Van Den Bergg and Meulemans, 1991 and Tsukamoto et al., 1995).

The main objective of this study was directed for evaluation of complexes of IBDV vaccine plus IBDV antiserum or hyperimmunized egg yolk in chicks that had high level of maternally derived antibodies.

According to the results of bursa/body weight ratios postvaccination, chicks vaccinated with IBDV intermediate-plus vaccine without addition of IBDV antibodies showed bursal atrophy. On the other hand, the IBDV-Ab complexes were sufficient to prevent bursal atrophy which satisfied the safety criterion of vaccine-Ab mixtures.

These findings are consistent with those reported by Whitfill et al. (1995) and Haddad et al. (1997).

All vaccine- $\mathrm{Ab}$ formulations induced an immune response to IBDV as demonstrated by presence of specific IBDV antibodies in sera of vaccinated birds in a higher rate compared to those vaccinated only with $1 \mathrm{BDV}$ vaccine without $\mathrm{Ab}$. These antibody titers correlated with protection from IBDV challenge at 28 days of age. These findings confirmed those reported by Whitfill et al. (1995) that IIBDV $-\Lambda \mathrm{b}$ complex vaccine allowed the bursae to develop normally which provide for a normal immunological response. Furthermore, the carly bursal atrophy from use of vaccine virus without $\mathrm{Ab}$ would be expected to reduce humoral immune response not only to IBDV vaccine but also to other vaccines or field pathogens. Thus, IBDV antibodies is nceded in complexes with IBDV vaccines to protect the bursal affection during few days post-vaccination and minimize immunosuppression (Pink, 1986 and McCormack et al., 1991).

The IBDV-Ab complex either as antiserum or in hypcrimmune egg yolk, demonstrated protective immunity against challenge virus at 28 days of age. Ilowever, egg yolk was found to induce a higher protection rate against challenge than that of antiserum. 
The IBDV-Ab complex vaccine has been previously shown to be effective and safe for vaccination of one-day-old SPF chickens (Whitfill et al., 1995). In addition, the use of IBDV-Ab complex vaccine in broiler type chicks with variable levels of IBDV maternal antibodies proved to be efficacious (Haddad et al., 1997, and Bi Yinggzuo et al., 2000).

It is worthy noting that, IBDV-Ab complex vaccine prepared from hyperimmune egg yolk is a novel mixture and proved more efficient and induced better protection and higher ELISA titers.

The superior results of IBDV- $\mathrm{Ab}$ complex prepared from hyperimmune egg yolk as evaluated by protection and estimation of antibody titers by ELISA test may be due to the character of egg yolk in stimulation of nonspecilic immunity and/or the nature of egg yolk as a natural adjuvant.

Based on the results of this study, it could be concluded that IBDV-Ab complex prepared from hyperimmune egg yolk is safe and imununogenic in commercial chicks with high levels of IBDV maternal antibodics than administration of the IBDV vaccine without $\mathrm{Ab}$.

\section{REFERENCES}

Bi Yinggzuo; Cao Yongchang; Lu Yingzi; Long Liping, and Shi Kongyun (2000): Elficacy of infectious bursal disease (IBD) virusantibody vaccine in broilers with maternal antibodies. Journal of South China Agricultural University, 21 (1): 75-77.

Guittet, M.; LeCog, H.; Picault, J. P.; Elerradossi, N. and Bennejean, G. (1992): Safety of infectious bursal disease vaccines: assessment of an acceptability threshold.

Dev. Biol. Stand., 79: 147-152.

Haddad, E. E.; Whitfill, C. E.; Avakian, A. P.; Ricks, C. A.; Andrews, P. D.; Thoma, J. A., and Wakenell, P. S. (1997): Eflicacy of a novel infectious bursdal disease virus immune complex vaccine in broiler chickens. $A$ vian Dis., 41: 882-889.

Lukert, $P . D$., and Saif, Y. M. (1997): Infectious bursal disease. In: Diseases of Poultry, B. W. Calnek, H. J. Barnes, C. W. Beard, L. R. McDougald and Y. M. Saif (Eds), 10 edn, pp. 721-738 (Ames, Iowa State University Press).

McCormack, W. T.; Tjoelker, L. W., and Thompson, C. B. (1991): Avian B-cell development: generation of an immunoglobulin repertoire by gene conversion. Ann. Rev. Immunol, 9:219-241. 
Pink, J. R. L. (1986): Counting components of the chickens B cell system. Immunol. Rev., 91: 115-128.

Rives, D. V.; Davidian, M. and Ley, D. H. (1991): Infectious bursal disease virus titers may be misleading. North Carolina State University, North Carolina Cooperative Extension Service, 15: $1-3$.

Saif-Edin, M. Aly, M., and Mousa, S. (1996): Status of infectious bursal disease in Egypt. I. Nature of last severe outbreaks. $4^{\text {tir }}$ Sci. Conf. of Egypt. Poult. Assoc., pp. 65-81.

Tsukamoto, K: Tanimura, N.; Kakita, S; Ota, K; Mase, M.; Imai, K. and Hihara, H. (1995): Efficacy of three live vaccines against highly virulent infectious bursal disease virus in chickens with or without maternal antibodies. Avian Dis., 39: 218-229.

Van Den Bergg, T. P., and Meulemans, G. (1991): Acute infectious bursal disease in poultry: protection afforded by matcrnally derived antibodies and interference with live vaccination. Avian Pathol., 20: 409-421.

Weisman, J., and Hitchner, S. B. (1978): Virus-neutralization versus agar-gel precipitin tests for detecting serological response to infectious bursal disease virus. Avian Dis., 22: 598-603.

Wintefield R. W.; Dhillon, A. S.; Thacker, H. L, and Alby, L. J. (1980): Immune response of white leghorn chickens from vaccination with different strains of infectious bursal disease virus and in the presence of maternal antibodies. Avian Dis., 24: 179-188.

Wintefield R. W., and Thacker, H. L. (1978): Immune response and pathogenicity of different strains of infectious bursal disease virus applied as vaccines. $A$ vian Dis., 22: 721-731.

Whitfill, C. E; Haddad, E. E., Ricks, C. A.; Skeeles, J. K. Newberry, L. A.; Beasley, J. N.; Andrews, J. K.; Thoma, J. A., and Wakenell, P. S. (1995): Determination of optimum formulation of a novel infgectious bursal disease virus (IBDV) vaccine constructed by mixing bursal discase antibody with IBDV. Avian Dis., 39: 687-699. 
Table 1: Average ELISA titers in groups of commercial cockereles vaccinated with different mixtures of IBDV vaccine and IBDV antiserum or IBDV hyper-immunized egg yolk at 7 days of age.

\begin{tabular}{|c|c|c|c|c|c|c|}
\hline \multirow[t]{3}{*}{ Groups } & \multirow[t]{3}{*}{ Treatment } & \multicolumn{5}{|c|}{ ELISA titers } \\
\hline & & \multicolumn{5}{|c|}{ Age in days } \\
\hline & & 1 & $7 *$ & 14 & 21 & 28 \\
\hline 1 & $\begin{array}{l}\text { Vaccine }+ \\
\text { Antiserum }(3200 \text { ELISA } \\
\text { titer })\end{array}$ & 5432 & 3140 & 2145 & 3265 & 3812 \\
\hline 2 & $\begin{array}{l}\text { Vaccine + } \\
\text { Antiserum }(4100 \text { ELISA } \\
\text { titer) }\end{array}$ & 5212 & 3060 & 2860 & 3355 & 3863 \\
\hline 3 & $\begin{array}{l}\text { Vaccine + } \\
\text { Antiserum ( } 6400 \text { ELISA } \\
\text { titer) }\end{array}$ & 4980 & 2835 & 3230 & 3168 & 4110 \\
\hline 4 & $\begin{array}{l}\text { Vaccine }+ \\
\text { Egg yolk (3100 ELISA } \\
\text { titer) }\end{array}$ & 5185 & 3035 & 2714 & 3930 & 4820 \\
\hline 5 & $\begin{array}{l}\text { Vaccine + } \\
\text { Egg yolk ( } 4200 \text { EIISA } \\
\text { titer) }\end{array}$ & 5020 & 3270 & 3424 & 4190 & 5216 \\
\hline 6 & $\begin{array}{l}\text { Vaccine }+ \\
\text { Egg yolk ( } 5800 \text { ELISA } \\
\text { titer) }\end{array}$ & 4860 & 2840 & 3868 & 4484 & 5870 \\
\hline 7 & Vaccine & 5110 & 3255 & 2460 & 1674 & 790 \\
\hline 8 & Unvaccinated Control & 5085 & 3085 & 2120 & 1100 & 512 \\
\hline
\end{tabular}


Table 2: Bursa/Body weight ratios in different groups vaccinated with different mixtures of IBDV vaccine and IBDV antiserum or IBDV hyper-immunized egg yolk.

\begin{tabular}{|c|l|c|c|c|}
\hline \multirow{2}{*}{ Groups } & \multicolumn{1}{|c|}{ Treatment } & \multicolumn{3}{c|}{ Bursa/Body weight ratios } \\
\cline { 2 - 5 } & & 2 & 3 & 4 \\
\hline 1 & $\begin{array}{l}\text { Vaccinc + } \\
\text { Antiserum (3200 ELISA } \\
\text { titer) }\end{array}$ & 3.12 & 2.14 & 2.66 \\
\hline 2 & $\begin{array}{l}\text { Vaccine + } \\
\text { Antiserum (4100 ELISA } \\
\text { titer) }\end{array}$ & 3.42 & 2.63 & 2.46 \\
\hline 3 & $\begin{array}{l}\text { Vaccine + } \\
\text { Antiserum (6400 ELISA } \\
\text { titer) }\end{array}$ & 3.81 & 2.78 & 2.55 \\
\hline 4 & $\begin{array}{l}\text { Vaccine + } \\
\text { Egg yolk (3100 ELISA } \\
\text { titer) }\end{array}$ & 3.65 & 2.82 & 2.75 \\
\hline 5 & $\begin{array}{l}\text { Vaccine + } \\
\text { Fgg yolk (4200 ELISA } \\
\text { titer) }\end{array}$ & 3.74 & 2.67 & 2.46 \\
\hline 6 & $\begin{array}{l}\text { Vaccinc + } \\
\text { Egg yolk (5800 ELISA } \\
\text { titer) }\end{array}$ & 3.91 & 2.71 & 2.84 \\
\hline 7 & Vaccine & 3.62 & 1.84 & 1.63 \\
\hline 8 & Unvaccinated Control & 3.73 & 3.22 & 3.12 \\
\hline
\end{tabular}


Table 3: Protection rates in chicks after challenge with highly virulent IBDV at 28 days of age.

\begin{tabular}{|c|c|c|c|}
\hline Groups & Treatment & $\begin{array}{c}\% \\
\text { Morbidity } \\
\end{array}$ & $\begin{array}{c}\% \\
\text { Mortality }\end{array}$ \\
\hline 1 & $\begin{array}{l}\text { Vaccine }+ \\
\text { Antiserum }(3200 \text { ELISA } \\
\text { titer) }\end{array}$ & 60 & 30 \\
\hline 2 & $\begin{array}{l}\text { Vaccine }+ \\
\text { Antiserum (4100 ELISA } \\
\text { titer) }\end{array}$ & 60 & 30 \\
\hline 3 & $\begin{array}{l}\text { Vaccine }+ \\
\text { Antiserum (6400 ELISA } \\
\text { titer) }\end{array}$ & 50 & 20 \\
\hline 4 & $\begin{array}{l}\text { Vaccine }+ \\
\text { Egg yolk ( } 3100 \text { ELISA } \\
\text { titer) }\end{array}$ & 40 & 20 \\
\hline 5 & $\begin{array}{l}\text { Vaccine }+ \\
\text { Egg yolk (4200 ELISA } \\
\text { titer) }\end{array}$ & 30 & 20 \\
\hline 6 & $\begin{array}{l}\text { Vaccine }+ \\
\text { Egg yolk ( } 5800 \text { ELISA } \\
\text { titer) }\end{array}$ & 40 & 10 \\
\hline 7 & Vaccine & 90 & 50 \\
\hline 8 & Unvaccinated Control & 100 & 80 \\
\hline
\end{tabular}

